\title{
Determination of Mercury (II) Ion on Aryl Amide-Type Podand-Modified Glassy Carbon Electrode
}

\author{
Sevgi Güney, Gülcemal Yıldız, and Gönül Yapar \\ Department of Chemistry, Faculty of Science and Letters, Istanbul Technical University, 34469, Maslak Istanbul, Turkey \\ Correspondence should be addressed to Sevgi Güney, kartal@itu.edu.tr
}

Received 30 December 2010; Revised 7 March 2011; Accepted 28 March 2011

Academic Editor: Farnoush Faridbod

Copyright () 2011 Sevgi Güney et al. This is an open access article distributed under the Creative Commons Attribution License, which permits unrestricted use, distribution, and reproduction in any medium, provided the original work is properly cited.

A new voltammetric sensor based on an aryl amide type podand, 1,8-bis(o-amidophenoxy)-3,6-dioxaoctane, (AAP) modified glassy carbon electrode, was described for the determination of trace level of mercury (II) ion by cyclic voltammetry (CV) and differential pulse voltammetry (DPV). A well-defined anodic peak corresponding to the oxidation of mercury on proposed electrode was obtained at $0.2 \mathrm{~V}$ versus $\mathrm{Ag} / \mathrm{AgCl}$ reference electrode. The effect of experimental parameters on differential voltammetric peak currents was investigated in acetate buffer solution of $\mathrm{pH} 7.0$ containing $1 \times 10^{-1} \mathrm{~mol} \mathrm{~L}^{-1} \mathrm{NaCl}$. Mercury (II) ion was preconcentrated at the modified electrode by forming complex with AAP under proper conditions and then reduced on the surface of the electrode. Interferences of $\mathrm{Cu}^{2+}, \mathrm{Pb}^{2+}, \mathrm{Fe}^{3+}, \mathrm{Cd}^{2+}$, and $\mathrm{Zn}^{2+}$ ions were also studied at two different concentration ratios with respect to mercury (II) ions. The modified electrode was applied to the determination of mercury (II) ions in seawater sample.

\section{Introduction}

Podands, which are the member of the crown-ether family, have an importance in supramolecular chemistry because of their applications in ion sensing and also have high productivity and selectivity in forming complexes with alkali, alkaline earth metal, and transition metal ions [1-3]. Podands could allow conformational changing in structure for the binding of a guest molecule because they have more flexibility than their crown-ether analogues [4]. Since podand-type ligands have ability to form of spheroidal cavities and strong binding sites, they have attracted considerable interest in recent years. Amide-type podands have an importance for producing the complexes possessing high fluorescent properties [5].

Determination of mercury is an important issue because of high toxicity, reactivity, and excessive mobility of mercury in environment. In addition, mercury has crucial risk to human health [6]. Therefore, there is a necessity of improving fast, sensitive, and selective analytical techniques for analysis of mercury. Current instrumental analysis methods, such as UV spectrophotometry [7], X-ray fluorescence [8], atomic fluorescence spectrometry (AFS) [9], cold vapor atomic fluorescence spectrometry [10], atomic absorption spectrometry (AAS) [11], cold vapor atomic absorption spectrometry [12], and inductively coupled plasma mass spectrometry [13], have been extensively employed for trace determination of mercury (II) ion in the laboratory conditions. Since they are expensive, time-consuming and complicated for in situ measuring, they are not suitable for point-of-use applications. Alternatively, electrochemical techniques could be used for the mercury determination, because these techniques are easier and cheaper than the instrumental analysis methods mentioned above.

Chemically modified electrodes (CMEs) have attracted great attention in the past decades since they improve the sensitivity and selectivity of electrochemical analysis methods [14]. Description and fabrication of CMEs have been mentioned in an IUPAC report [15]. CMEs have various advantages, such as low cost, short analysis time, high sensitivity and selectivity in electroanalytical determinations of different compounds [16]. They are also used in different applications, for example, corrosion protection, selective electroorganic synthesis, solar energy conversion and 
storage, molecular electronics, and electrochromic display devices [17]. Modification of the electrode surfaces with appropriate modifiers enhances the selectivity and sensitivity of electroanalytical methods. There are several ways to modify the working electrode surface, for example, electrochemical, chemical, or physical methods. Stripping electrochemical technique is an alternative method for mercury determination due to its versatility, sensitivity, and low cost [17]. A number of articles have been published for the analysis of mercury (II) ion by CMEs [18-23]. The limit of detection (LOD) was argued in the literature for the determination of mercury (II) ion by CMEs which were approximately in the range of $10^{-9} \mathrm{M}$ as same as our current work. Furthermore, there has been no study in the literature for the determination of mercury (II) ion with AAP-modified electrode yet.

In the present study, the aryl amide type podand, AAP, was synthesized according to our previous work [24]. AAP modified glassy carbon electrode (AAP/GCE) was prepared, and differential pulse anodic stripping voltammetry was used for analytical response of mercury (II) ions. The effect of analytical parameters such as $\mathrm{pH}$, deposition potential, deposition time, and the amount of AAP as modifying agent were investigated. Interference effects of other metallic ions that might also form complexes with $\mathrm{Cl}^{-}$ion and the repeatability of the method were investigated, and also, detection mechanism was proposed. The accuracy of method was tested in the artificial seawater samples. AAP is a hopeful modifying agent in sensor application for determination of mercury (II) ion in mixture of aqueous solution compared with the other crown-ether molecules since it can be easily synthesized and also modified on electrode surface.

\section{Experimental}

2.1. Synthesis of $A A P$. Into a flask $(50 \mathrm{~mL})$ salicylamide $(2.74 \mathrm{~g}$, $20 \mathrm{mmoL}), \mathrm{Na}_{2} \mathrm{CO}_{3}(2.36 \mathrm{~g}, 22 \mathrm{mmoL}), \mathrm{DMF}(20 \mathrm{~mL})$, and 1,8-dichloro-3,6-dioxaoctane $(1.87 \mathrm{~g}, 10 \mathrm{mmoL})$ were added and heated at $80-85^{\circ} \mathrm{C}$ for $72 \mathrm{~h}$. Then, the mixture of reaction was poured into water $(200 \mathrm{~mL})$. The filtered residue was washed with water and dried at $75^{\circ} \mathrm{C}$. The crude product was dissolved in $\mathrm{CH}_{2} \mathrm{Cl}_{2}$ and chromatographed on silica gel $(50 \mathrm{~g})$ with $\mathrm{CH}_{2} \mathrm{Cl}_{2} /$ acetone: $3 / 2(\mathrm{v} / \mathrm{v}) .3 .31 \mathrm{~g}, 85 \%$ yield, colorless leafs. Structure of synthesized AAP is shown in Scheme 1.

2.2. Reagents and Materials. All chemicals used in these experiments were of the highest purity (used without further purification) and were obtained from Merck, Fluka, and Riedel de Haen Chemical Companies. Salicylamide (Alfa Aesar), 1,8-dichloro-3,6-dioxaoctane and DMF (Fluka), silica gel 40-63 u $60 \mathrm{~A}$ (Fluorochem), $\mathrm{Hg}\left(\mathrm{CH}_{3} \mathrm{COO}\right)_{2}$ (Merck). All solutions were prepared by using ultrapure water from Millipore MilliQ System (sensitivity equal to $18 \mathrm{M} \Omega$ ). A stock solution of $1 \times 10^{-2} \mathrm{M}$ AAP was prepared in ethyl alcohol. Buffer solutions were prepared by adjustment of $\mathrm{pH}$ with $\mathrm{HCl}$ or $\mathrm{KOH}$. All electrochemical experiments were carried out in a conventional three-electrode system under the room temperature $\left(25 \pm 1^{\circ} \mathrm{C}\right)$.

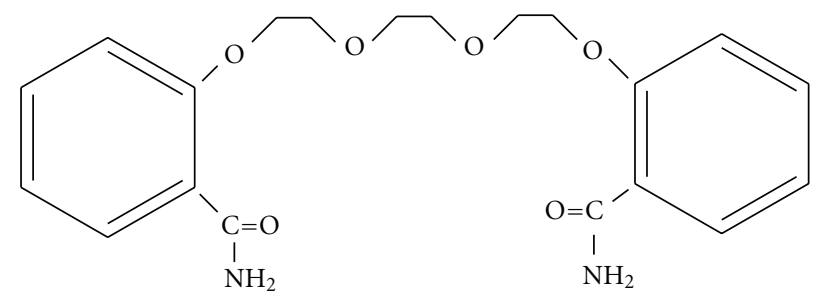

Scheme 1: The structure of the 1, 8-bis (o-amidophenoxy)-3, 6dioxaoctane.

2.3. Instrumentation. All electrochemical measurements were carried out on Autolab PGSTAT 30 (Eco Chemie) potentiostat/galvanostat. A classical three-electrode cell consists of $\mathrm{Ag} / \mathrm{AgCl}(3 \mathrm{M} \mathrm{KCl})$ reference electrode, a platinum wire counter electrode (BAS MW 1032), and a glassy carbon working electrode (the diameter of working electrode is $3 \mathrm{~mm}$, BAS MF-2012). Instrumental parameters were as follows: pulse amplitude $50 \mathrm{mV}$, pulse width $50 \mathrm{~ms}$, potential step $4 \mathrm{mV}$ pulse period $0.2 \mathrm{~s}$, and scan rate $50 \mathrm{mV} \mathrm{s}^{-1}$. Solutions were deoxygenated for 10 minutes with highgrade nitrogen, and an inert atmosphere was obtained over the solutions during analysis. The solutions were adjusted using a pH meter (WTW Inolab pH 720). An ultrasonic bath was used for preparing the homogeneous solutions (Bandelin Sonorex RK 100H). Spin coating of the glassy carbon electrode was performed by using IKEA RW 20 rotator.

\subsection{Preparation of the AAP Modified Glassy Carbon Electrode} $(A A P / G C E)$. Before the modification, surface of the glassy carbon electrode (GCE) was polished to gain a mirror-like appearance with $1.0,0.3$, and $0.05 \mu \mathrm{m}$ of aluminum oxide slurry, respectively. After the polishing, GCE was sonicated twice in ethyl alcohol and ultrapure water for $5 \mathrm{~min}$ each. After that, electrochemical pretreatment was performed by the potential step which was applied at $+0.8 \mathrm{~V}$ for 5 minutes and $-1.4 \mathrm{~V}$ for 1 minute in $1 \times 10^{-1} \mathrm{moL} \mathrm{L}^{-1} \mathrm{H}_{2} \mathrm{SO}_{4}$ solution, respectively. Then, modification of the surface of the electrode with AAP was performed by spin coating employing a rotator with a speed of $300 \mathrm{rpm}$. Two drops of $10 \mu \mathrm{L}$ of $5.0 \times 10^{-3} \mathrm{moL} \mathrm{L}^{-1}$ AAP dissolved in ethyl alcohol were dropped on the spinning electrode and then dried in room temperature.

2.5. Analytical Procedure. The procedure of preconcentration and voltammetric determination of mercury (II) ion on AAP modified electrode includes the following steps: (1) modifying the GC electrode with AAP, (2) dipping of the modified electrode in aqueous solution of mercury (II) at open circuit, (3) electrochemical reduction of mercury (II) ions to metallic mercury at $-0.8 \mathrm{~V}$ for $12 \mathrm{~min}$ by stirring in an acetate buffer solution of $\mathrm{pH} 7.0$ containing $0.1 \mathrm{moL} \mathrm{L}^{-1} \mathrm{NaCl}$, and (4) voltammetric determination of mercury (II) ions by DPV from $-0.1 \mathrm{~V}$ to $0.4 \mathrm{~V}$ in the same solution. The modified electrode was reused by holding the potential $+0.8 \mathrm{~V}$ for $3 \mathrm{~min}$. to remove any previous 
deposits for repeated determinations. AAP-modified glassy carbon electrode was tested in a new buffer solution without mercury (II) ions, before each experiment.

\section{Results and Discussion}

3.1. Voltammetric Behavior of Mercury (II) on AAP-Modified GCE. The capability of AAP/GCE for preconcentration and determination of mercury (II) was investigated. Figure 1 shows the CVs at AAP-modified GCE in the absence and presence of mercury (II) after preconcentration.

As can be seen in Figure 1, a well-defined anodic peak $\left(I_{\mathrm{p}}\right)$ was obtained at $0.2 \mathrm{~V}$ (solid line) due to the electrochemical oxidation of mercury (0) to mercury (II), and mercury (0) was produced by the electrochemical reduction of captured mercury (II) at the deposition step under negative potentials. Furthermore, no mercury peak was observed in the absence of mercury (II) as a control experiment (dashed line).

These experimental results showed that mercury (II) ions from the solution can form strong $\mathrm{HgCl}_{4}^{2-}$ complex with $\mathrm{Cl}^{-}$ ions. Then $\mathrm{HgCl}_{4}^{2-}$ complex is deposited on the modified electrode surface and reduced to $\mathrm{Hg}^{0}$ following $\mathrm{Hg}^{0}$ being oxidized to $\mathrm{Hg}^{2+}$ ion. Therefore, the possible electrochemical reaction mechanism can be illustrated as follows.

\section{Deposition:}

$$
\begin{gathered}
\left(\mathrm{HgCl}_{4}{ }^{2-}\right)_{\text {solution }}+\left(\frac{\mathrm{AAP}}{G C E}\right)_{\text {surface }} \\
\longrightarrow\left(\mathrm{HgCl}_{4}{ }^{2-}-\frac{\mathrm{AAP}}{G C E}\right)_{\text {surface }}
\end{gathered}
$$

Reduction:

$$
\begin{gathered}
\left(\mathrm{HgCl}_{4}{ }^{2-}-\frac{\mathrm{AAP}}{G C E}\right)_{\text {surface }}+2 \mathrm{e}^{-} \\
\longrightarrow\left(\mathrm{Hg}^{0}-\frac{\mathrm{AAP}}{G C E}\right)_{\text {surface }}+4 \mathrm{Cl}^{-} .
\end{gathered}
$$

Oxidation:

$$
\begin{aligned}
& \left(\mathrm{Hg}^{0}-\frac{\mathrm{AAP}}{G C E}\right)_{\text {surface }} \\
& \quad \longrightarrow\left(\mathrm{Hg}^{2+}\right)_{\text {solution }}+\left(\frac{\mathrm{AAP}}{G C E}\right)_{\text {surface }}+2 \mathrm{e}^{-}
\end{aligned}
$$

3.2. Optimization of Measurement Condition. In order to obtain optimum experimental conditions for mercury (II) determination, several parameters were investigated such as type and $\mathrm{pH}$ of the buffer solution, AAP concentration on electrode surface, deposition potential, and deposition time.

The effect of supporting electrolytes was investigated in acetate, phosphate, and B-R buffer solutions, respectively. The results indicated that voltammetric peaks were observed in all electrolyte solutions, but the electrochemical response of mercury (II) ion in $0.1 \mathrm{moLL}^{-1} \mathrm{HAc}+0.1 \mathrm{moLL}^{-1}$

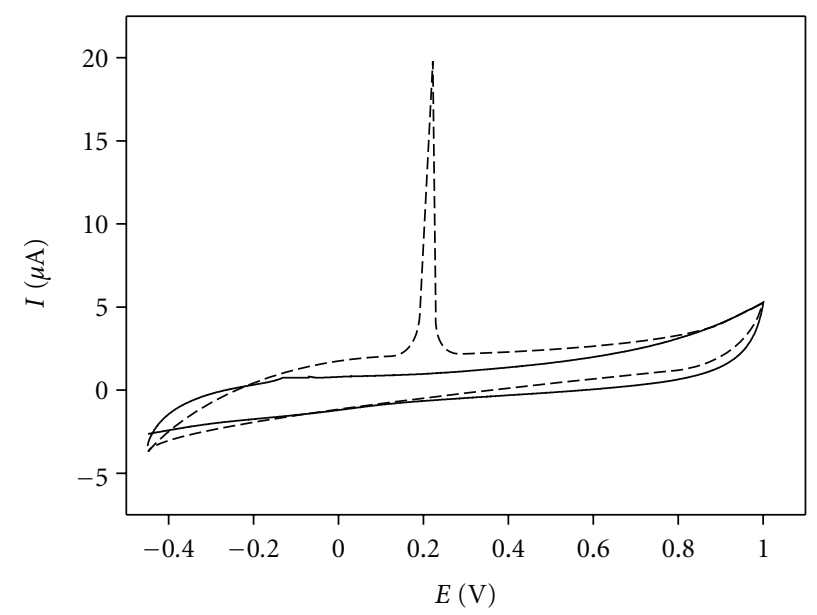

Figure 1: Cyclic voltammograms of blank solution (solid line) and $5 \times 10^{-7} \mathrm{moLL}^{-1}$ of $\mathrm{Hg}^{2+}$ at AAP modified GC electrode (dashed line). Electrolyte: $0.1 \mathrm{~mol} \mathrm{~L}^{-1} \mathrm{HAc}+0.1 \mathrm{~mol} \mathrm{~L}^{-1} \mathrm{NaCl}(\mathrm{pH}$ 7.0) solution. Deposition time $\left(t_{\mathrm{d}}\right): 12 \mathrm{~min}$; deposition potential $\left(E_{\mathrm{d}}\right):-0.8 \mathrm{~V}$; scan rate $(\mathrm{v}): 50 \mathrm{mV} / \mathrm{s}$. GC electrode modified with $0.125 \mu \mathrm{moL}$ AAP.

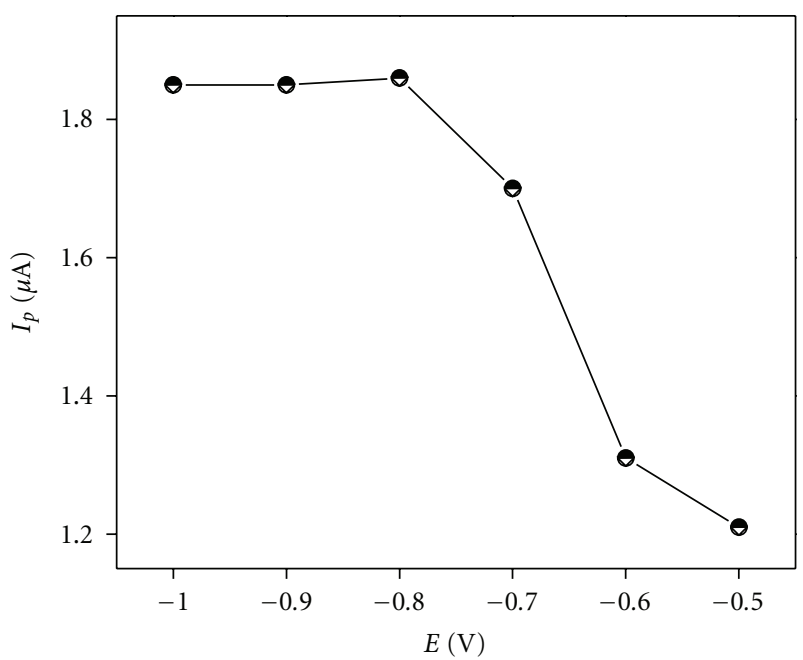

FIGURE 2: Effects of deposition potential on DPV peak currents for $5 \times 10^{-7} \mathrm{moL}$ of $\mathrm{Hg}^{2+}$ at AAP modified GC electrode. Electrolyte: $0.1 \mathrm{~mol} \mathrm{~L}^{-1} \mathrm{HAc}+0.1 \mathrm{~mol} \mathrm{~L}^{-1} \mathrm{NaCl}(\mathrm{pH} 7.0)$ solution. GC electrode modified with $0.063 \mu \mathrm{mol}$ AAP, $t_{\mathrm{d}}: 10 \mathrm{~min}$

$\mathrm{NaCl}$ solution gave the best shaped and largest peak current among these solutions. Therefore, this supporting electrolyte was used in following experiments. The effect of $\mathrm{pH}$ on the anodic stripping peak currents of mercury (II) ion on the modified electrode was studied by differential pulse voltammetry, and the graph of the peak currents against $\mathrm{pH}$ was plotted (data was not shown). AAP modified glassy carbon electrode showed the stable activity over the range of $\mathrm{pH} 3.0-12.0$, and the best peak height and shape were obtained at $\mathrm{pH}$ 7.0. This $\mathrm{pH}$-dependent behavior of mercury (II) ion can be explained by the fact that different protonation ability of AAP affects the formation constant of 


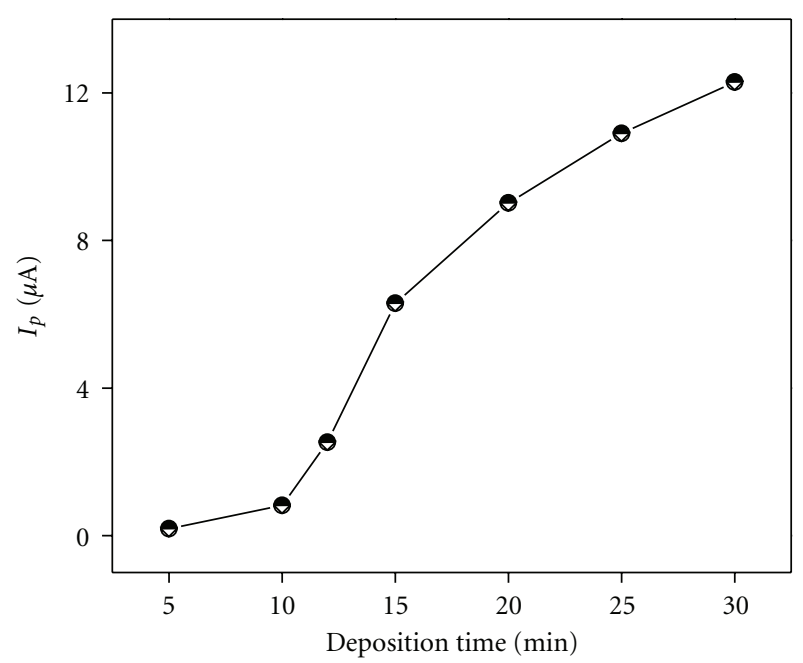

FIgURE 3: Effects of deposition time on DPV peak currents for 5 $\times 10^{-7} \mathrm{~mol} \mathrm{~L}^{-1} \mathrm{Hg}^{2+}$ at AAP modified GCE. $E_{\mathrm{d}}$ : $-0.8 \mathrm{~V}$. The other conditions are the same as in Figure 2.

the complex between mercury (II) ions and AAP at different $\mathrm{pH}$.

Deposition potential $\left(E_{\mathrm{d}}\right)$ is an important parameter that affects the sensitivity of detection. AAP-modified GCE was kept at the potentials varying between $-0.5 \mathrm{~V}$ and $-1.0 \mathrm{~V}$ for $10 \mathrm{~min}$. in a solution of $5 \times 10^{-7} \mathrm{moL} \mathrm{L}^{-1}$ mercury (II), and DPV was performed. The change in DPV peak currents depending on the deposition potentials is shown in Figure 2. As can be seen in Figure 2, the peak current increases with the deposition potentials reaching a plateau at about $-0.8 \mathrm{~V}$, therefore, this potential was selected as optimal deposition potential.

The effect of deposition time $\left(t_{\mathrm{d}}\right)$ for mercury (II) determination is shown in Figure 3. The peak current increased with increasing deposition time. The longer the deposition time, the higher the sensitivity obtained in stripping voltammetry, but with narrow detection range results. In this detection system, deposition saturation was reached for $5 \times 10^{-7} \mathrm{moL} \mathrm{L}^{-1} \mathrm{Hg}^{2+}$ by the preconcentration of 30 minutes as shown in Figure 3. Considering the detection limit and linear range, deposition time of 12 minutes was chosen in this study.

The concentration of AAP on the electrode surface affects the deposition capacity of mercury (II) ion and changes the oxidation current (Figure 4). As can be seen in Figure 4, the initial peak current increased up to $0.125 \mu \mathrm{moL}$ of AAP since the reactive areas involved in the complexation reaction between mercury and AAP increase with AAP concentration. At the higher concentration of $0.125 \mu \mathrm{moL}$ of AAP, the electron transfer between the mercury and electrode was blocked resulting in decrease of current. Therefore, the concentration of $0.125 \mu \mathrm{moL}$ was selected as the optimum AAP concentration.

3.3. Interference of Foreign Metal Ions. Under optimized experimental conditions mentioned above, the possible interferences of other metal ions like $\mathrm{Cd}^{2+}, \mathrm{Pb}^{2+}, \mathrm{Fe}^{3+}$,

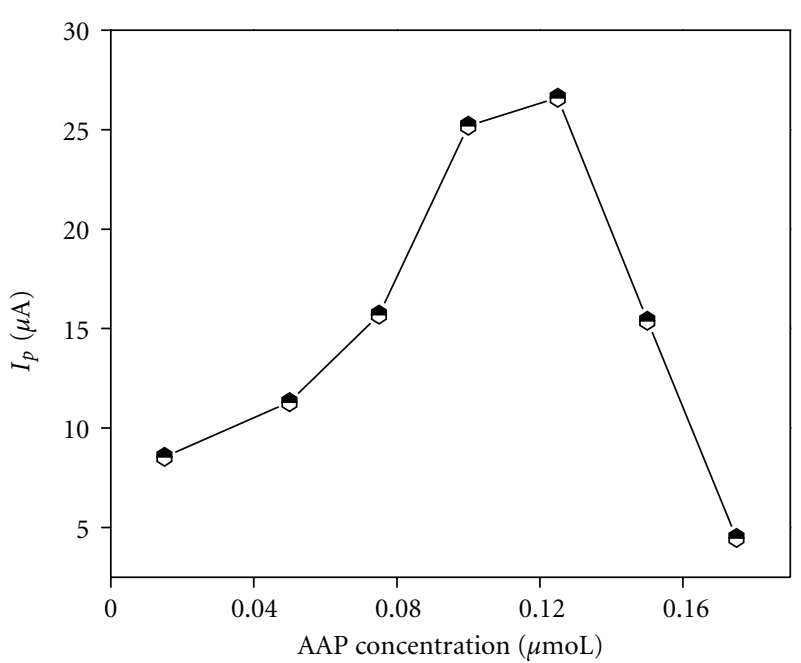

FIGURE 4: Effects of electrode surface concentration of AAP on DPV peak currents for $5 \times 10^{-7} \mathrm{~mol} \mathrm{~L}^{-1} \mathrm{Hg}^{2+}$ at modified electrode. Electrolyte: $0.1 \mathrm{~mol} \mathrm{~L}^{-1} \mathrm{HAc}+0.1 \mathrm{~mol} \mathrm{~L}^{-1} \mathrm{NaCl}(\mathrm{pH} 7.0)$ solution. $E_{\mathrm{d}}:-0.8 \mathrm{~V}, t_{\mathrm{d}}: 12 \mathrm{~min}$.

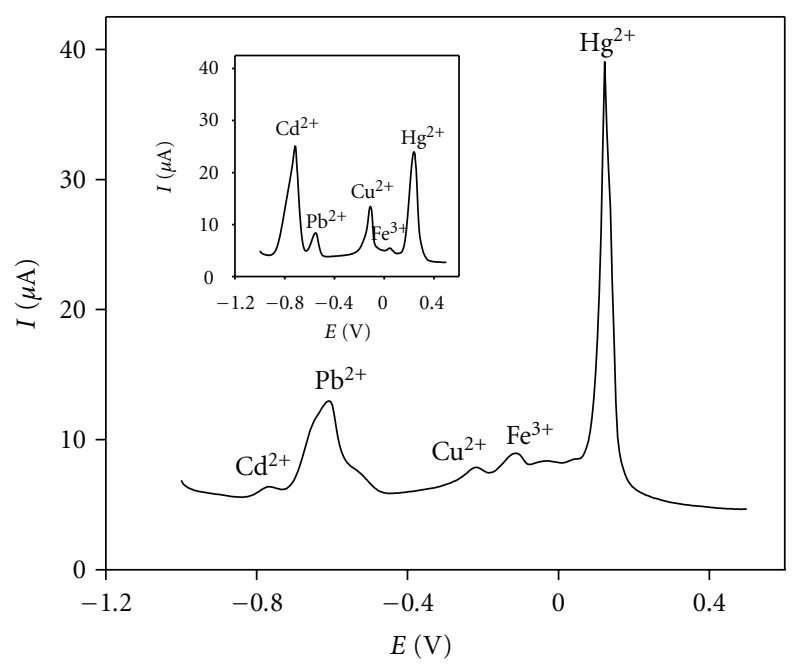

Figure 5: DPVs of $1 \mu \mathrm{mol} \mathrm{L}^{-1} \mathrm{Hg}^{2+}$ in the presence of $10 \mu \mathrm{mol} \mathrm{L}-1$ each of $\mathrm{Cd}^{2+}, \mathrm{Pb}^{2+}, \mathrm{Cu}^{2+}, \mathrm{Fe}^{3+}, \mathrm{Zn}^{2+}$ ions at AAP-modified GCE. The other conditions are those in Figure 4. Inset figure: DPVs of the same electrolyte on bare GCE.

and $\mathrm{Cu}^{2+}$ for the determination of $1 \mu \mathrm{moL} \mathrm{L}{ }^{-1} \mu \mathrm{Hg}^{2+}$ were examined with AAP-modified electrode (Figure 5). The effect of the inference was tested in two compositions of the solution containing 1 and $10 \mu \mathrm{moL} \mathrm{L}^{-1}$ of metal ions. The same experiment was also carried out with unmodified glassy carbon electrode (Figure 5, inset).

As can be seen in Figure 5, the peak current belonging to $\mathrm{Cd}^{2+}$ decreased but the peak current of mercury (II) was twofold increased and shifted to more negative potential on modified electrode. On the other hand, $\mathrm{Fe}^{3+}$ and $\mathrm{Cu}^{2+}$ exhibit very small peak currents comparing to that of mercury (II). $\mathrm{Pb}^{2+}$ ion does not affect the mercury (II) peak current since the peak potential of $\mathrm{Pb}^{2+}$ is more negative than that of the 


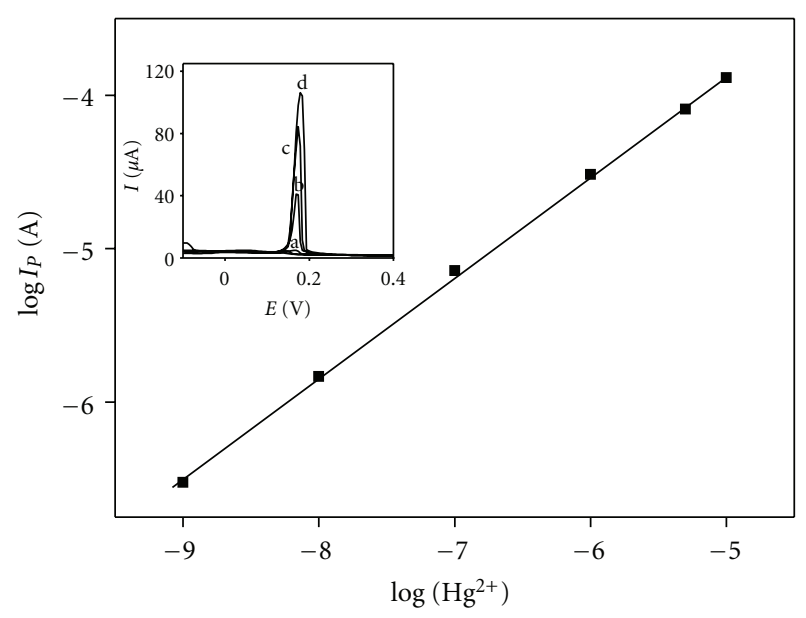

Figure 6: Calibration plot of $\log I_{p}$ versus $\log \left[\mathrm{Hg}^{2+}\right]$. Inset figure: DPVs of different concentrations of $\mathrm{Hg}^{2+}$ (a) $1.0 \times 10^{-9}$, (b) $1.0 \times$ $10^{-8}$, (c) $1.0 \times 10^{-7}$, (d) $1.0 \times 10^{-6} \mathrm{~mol} \mathrm{~L}-1$. The other conditions are same as in Figure 4.

TABLE 1: The effect of interference of some metal ions on mercury determination under optimized experimental conditions at AAP/GCE. Solution contains $1 \mu \mathrm{moL} \mathrm{L}-1 \mathrm{Hg} 2+$ and interferences are (a) $1 \mu \mathrm{moLL}-1$ and (b) $10 \mu \mathrm{moL} \mathrm{L}-1$.

\begin{tabular}{lcccc}
\hline cation & $I_{p}\left(\mathrm{Hg}^{2+}\right) \mu \mathrm{A}$ & Recovery $\%$ & $I_{p}\left(\mathrm{Hg}^{2+}\right) \mu \mathrm{A}$ & Recovery $\%$ \\
\hline $\mathrm{Hg}^{2+}$ & 49 & 100 & 49 & 100 \\
$\mathrm{Fe}^{3+}$ & $57^{\mathrm{a}}$ & 116 & $66^{\mathrm{b}}$ & 135 \\
$\mathrm{Zn}^{2+}$ & $47^{\mathrm{a}}$ & 96 & $46^{\mathrm{b}}$ & 94 \\
$\mathrm{~Pb}^{2+}$ & $48^{\mathrm{a}}$ & 99 & $48^{\mathrm{b}}$ & 99 \\
$\mathrm{Cu}^{2+}$ & $54^{\mathrm{a}}$ & 110 & $64^{\mathrm{b}}$ & 130 \\
$\mathrm{Cd}^{2+}$ & $46^{\mathrm{a}}$ & 94 & $45^{\mathrm{b}}$ & 92 \\
\hline
\end{tabular}

TABle 2: Determination of $\mathrm{Hg} 2+$ in artificial seawater samples by DPV at AAP/GCE.

\begin{tabular}{llcc}
\hline $\begin{array}{l}\text { Added } \\
\mathrm{Hg}^{2+}\left(10^{-7} \mathrm{M}\right)\end{array}$ & $\begin{array}{l}\text { Found } \\
\mathrm{Hg}^{2+}\left(10^{-7} \mathrm{M}\right) \\
(n=6)\end{array}$ & Recovery, \% & $\begin{array}{l}\mathrm{RSD}, \% \\
(n=6)\end{array}$ \\
\hline 5.0 & $4.93 \pm 0.11$ & 98.6 & 2.23 \\
8.0 & $7.92 \pm 0.15$ & 99.0 & 1.89 \\
10.0 & $9.91 \pm 0.14$ & 99.1 & 1.41 \\
\hline
\end{tabular}

mercury (II). The interference effects of some metal ions are given in Table 1.

3.4. Calibration Plot, Limit of Detection, and Validation of Method. Under the optimum conditions described above, the reproducibility of the proposed method was evaluated with the solution of $1 \times 10^{-7} \mathrm{~mol} \mathrm{~L}^{-1}$ mercury (II) for six repetitive measurements. The relative standard deviation (RSD) was $1.84 \%$ which presented the good reproducibility of the proposed modified electrode. Linearity of the calibration curve was also investigated in the mercury (II) concentration ranges from $1 \times 10^{-9} \mathrm{~mol} \mathrm{~L}^{-1}$ to $1 \times$ $10^{-5} \mathrm{~mol} \mathrm{~L}^{-1}$ (Figure 6, inset).
The calibration plot (Figure 6 ) shows a good linear behavior with correlation coefficient $\left(R^{2}\right)$ of 0.9997 , and the resulting equation is $\log I(A)=2-0.5954+0.6556 \log C$ $\left(\mathrm{mol} \mathrm{L}^{-1}\right)$. The limit of detection is $4 \times 10^{-9} \mathrm{~mol} \mathrm{~L}^{-1}(\mathrm{~S} / \mathrm{N}=$ $3)$. These values verified the sensitivity of the proposed method for the determination of mercury (II). AAP/GCE can be stored about 4 weeks, and the decrease in response was $2.54 \%$, indicating the good stability of electrode. When the proposed electrode was compared with the other macrocyclic kinds of modified electrodes for mercury (II) determination, it can be seen that the detection limits of them were in the range of $1.0 \times 10^{-8}$ and $1.0 \times 10^{-7} \mathrm{~mol} \mathrm{~L}^{-1}[22,25-28]$. Consequently, AAP modified electrode could be a promising voltammetric sensor for trace analysis of mercury (II) ion.

3.5. Analytical Applications. The accuracy of the proposed method was tested in artificial seawater sample by spiking known concentrations of mercury (II) ion. Artificial seawater was prepared according to the literature [29]. Determination of mercury (II) concentration was performed by the calibration curve method. The experimental parameters were the same as described above, and the results are summarized in Table 2.

\section{Conclusion}

A new kind of chemically modified electrode has been developed for highly selective and sensitive determination of mercury (II) by forming complex with AAP. It was shown that AAP-coated glassy carbon electrode could be used for determination of mercury (II) ion from aqueous solutions since the sensitivity is greatly improved. The immersion of electrode into the solution containing $\mathrm{Cl}^{-}$ion increased the deposition of mercury (II) ion on the electrode surface due to formation of $\mathrm{HgCl}_{4}^{2-}$ complex. The results also show that AAP-modified electrode has a good reproducibility, wide linear range, high selectivity, and low detection limit. It can be a very good alternative to expensive analytical techniques such as atomic absorption spectrometry and ICPMS. The preparation and application of proposed modified electrode are simpler and also cheaper than those of the other electrodes modified with more complex and more expensive modifying agents.

\section{Acknowledgments}

The authors would like to thank Istanbul Technical University Research Foundation (ITU-BAP Project no. 32646) and Scientific and Technical Research Council of Turkey (TUBITAK Project no. 104T079) for their financial support.

\section{References}

[1] G. W. Gokel, "Comprehensive supramolecular chemistry," in Molecular Recognition: Receptors for Cationic Guest, J. L. Atwood, Ed., vol. 1, chapter 1, Pergamon, New York, NY, USA, 1996.

[2] G. Yidiz, G. Yapar, and C. Erk, "The association constants of $\mathrm{Na}$ with dibenzo[3n]crown-n in THF/water using ISE," Talanta, vol. 64, no. 4, pp. 865-868, 2004. 
[3] H. J. Kim, D. S. Park, M. H. Hyun, and Y. B. Shim, "Determination of $\mathrm{Hg}$ ion with a 1,11-bis(8-quinoyloxy)3,6,9-trioxaundecane-modified glassy carbon electrode using spin-coating technique," Electroanalysis, vol. 10, no. 5, pp. 303-306, 1998.

[4] J. W. Steed and J. L. Atwood, Supramolecular Chemistry, Wiley, New York, NY, USA, 2000.

[5] Y. Zhao, Y. Tang, W. S. Liu, N. Tang, and M. Y. Tan, "Synthesis and infrared and fluorescent properties of rare earth complexes with a new aryl amide podand," Spectrochimica ActaPart A, vol. 65, no. 2, pp. 372-377, 2006.

[6] W. F. Fitzgerald, C. H. Lamborg, and C. R. Hammerschmidt, "Marine biogeochemical cycling of mercury," Chemical Reviews, vol. 107, no. 2, pp. 641-662, 2007.

[7] M. S. Jeoung and H. S. Choi, "Spectrophotometric determination of trace $\mathrm{Hg}(\mathrm{II})$ in cetyltrimethylammonium bromide media," Bulletin of the Korean Chemical Society, vol. 25, no. 12, pp. 1877-1880, 2004.

[8] E. K. Pavlos and G. K. K. Nikolaos, "Selective mercury determination after membrane complexation and total reflection X-ray fluorescence analysis," Analytical Chemistry, vol. 76, no. 15, pp. 4315-4319, 2004.

[9] L. Rahman, W. T. Corns, D. W. Bryce, and P. B. Stockwell, "Determination of mercury, selenium, bismuth, arsenic and antimony in human hair by microwave digestion atomic fluorescence spectrometry," Talanta, vol. 52, no. 5, pp. 833$843,2000$.

[10] M. Roulet, M. Lucotte, J. R. D. Guimarães, and I. Rheault, "Methylmercury in water, seston, and epiphyton of an Amazonian river and its floodplain, Tapajós River, Brazil," Science of the Total Environment, vol. 261, pp. 43-59, 2000.

[11] J. L. Capelo, I. Lavilla, and C. Bendicho, "Room temperature sonolysis-based advanced oxidation process for degradation of organomercurials: application to determination of inorganic and total mercury in waters by flow injection-cold vapor atomic absorption spectrometry," Analytical Chemistry, vol. 72, no. 20, pp. 4979-4984, 2000.

[12] S. C. Hight and J. Cheng, "Determination of total mercury in seafood by cold vapor-atomic absorption spectroscopy (CVAAS) after microwave decomposition," Food Chemistry, vol. 91, no. 3, pp. 557-570, 2005.

[13] J. C. A. Wuillouda, R. G. Wuillouda et al., "Gas chromatography/plasma spectrometry- an important analytical tool for elemental speciation studies," Spectrochimica Acta-Part B, vol. 59, no. 6, pp. 755-792, 2004.

[14] P. R. Moses and R. W. Murray, "Chemically modified electrodes. 3. SnO and $\mathrm{TiO}$ electrodes bearing an electroactive reagent [11]," Journal of the American Chemical Society, vol. 98, no. 23, pp. 7435-7436, 1976.

[15] R. A. Durst, A. J. Bäumner, R. W. Murray, R. P. Buck, and C. P. Andrieux, "Chemically modified electrodes: recommended terminology and definitions," Pure and Applied Chemistry, vol. 69, no. 6, pp. 1317-1323, 1997.

[16] C. Hu, K. Wu, X. Dai, and S. Hu, "Simultaneous determination of lead(II) and cadmium(II) at a diacetyldioxime modified carbon paste electrode by differential pulse stripping voltammetry," Talanta, vol. 60, no. 1, pp. 17-24, 2003.

[17] A. Giacomino, O. Abollino, M. Malandrino, and E. Mentasti, "Parameters affecting the determination of mercury by anodic stripping voltammetry using a gold electrode," Talanta, vol. 75 , no. 1, pp. 266-273, 2008.
[18] N. L. Dias Filho and D. R. do Carmo, "Stripping voltammetry of mercury(II) with a chemically modified carbon paste electrode containing silica gel functionalized with 2,5dimercapto-1,3,4- thiadiazole," Electroanalysis, vol. 17, no. 17, pp. 1540-1546, 2005.

[19] H. Zejli, P. Sharrock, J. L. H. H. De Cisneros, I. NaranjoRodriguez, and K. R. Temsamani, "Voltammetric determination of trace mercury at a sonogel-carbon electrode modified with poly-3-methylthiophene," Talanta, vol. 68, no. 1, pp. 7985, 2005.

[20] M. Colilla, M. A. Mendiola, J. R. Procopio, and M. T. Sevilla, "Application of a carbon paste electrode modified with a schiff base ligand to mercury speciation in water," Electroanalysis, vol. 17, no. 11, pp. 933-940, 2005.

[21] A. Widmann and C. M. G. van den Berg, "Mercury detection in seawater using a mercaptoacetic acid modified gold microwire electrode," Electroanalysis, vol. 17, no. 10, pp. 825831, 2005.

[22] H. M. Dong, L. Lin, H. Zheng, G. Zhao, and B. Ye, "Electrode modified with Langmuir-Blodgett (LB) film of calixarenes for preconcentration and stripping analysis of $\mathrm{Hg}(\mathrm{II})$, , Electroanalysis, vol. 18, no. 12, pp. 1202-1207, 2006.

[23] N. L. D. Filho, D. R. D. Carmo, and A. H. Rosa, "An electroanalytical application of 2-aminothiazole-modified silica gel after adsorption and separation of $\mathrm{Hg}$ (II) from heavy metals in aqueous solution," Electrochimica Acta, vol. 52, no. 3, pp. 965-972, 2006.

[24] S. Güney, G. Yapar, O. Güney, and G. Yildiz, "Elucidation of mercury ion binding property of a new aryl amide type podand by electrochemical and fluorescence measurements," Analytical Letters, vol. 42, no. 17, pp. 2879-2892, 2009.

[25] J. Q. Lu, X. W. He, X. S. Zeng, Q. J. Wan, and Z. Z. Zhang, "Voltammetric determination of mercury (II) in aqueous media using glassy carbon electrodes modified with novel calix[4] arene," Talanta, vol. 59, no. 3, pp. 553-560, 2003.

[26] A. A. Ensafi and M. Fouladgar, "A sensitive and selective bulk optode for determination of $\mathrm{Hg}$ (II) based on hexathiacyclooctadecane and chromoionophore V," Sensors and Actuators, B, vol. 136, no. 2, pp. 326-331, 2009.

[27] G. Roa-Morales, M. T. Ramírez-Silva, R. L. González, L. Galicia, and M. Romero-Romo, "Electrochemical characterization and determination of mercury using carbon paste electrodes modified with cyclodextrins," Electroanalysis, vol. 17, no. 8, pp. 694-700, 2005.

[28] C. Dridi, M. B. Ali, F. Vocanson et al., "Electrical and optical study on modified Thiacalix(4)arene sensing molecules: application to Hg ion detection," Materials Science and Engineering C, vol. 28, no. 5-6, pp. 765-770, 2008.

[29] D. R. Kester, I. W. Duedall, D. N. Connors, and R. M. Pytkowicz, "Preparation of artificial seawater," Limnology \& Oceanography, vol. 12, pp. 176-179, 1967. 


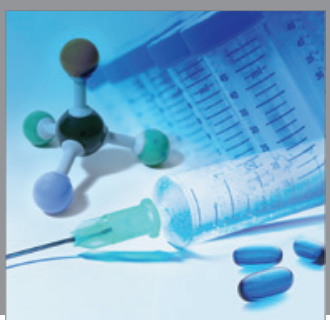

International Journal of

Medicinal Chemistry

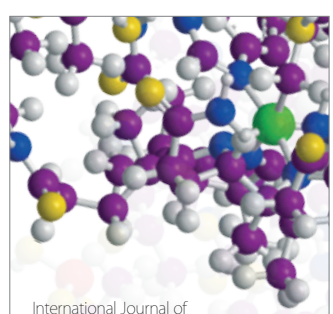

Carbohydrate Chemistry

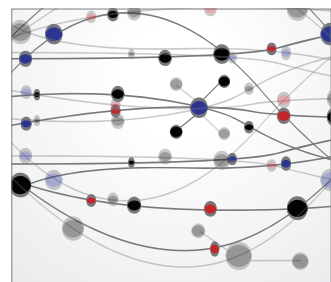

The Scientific World Journal
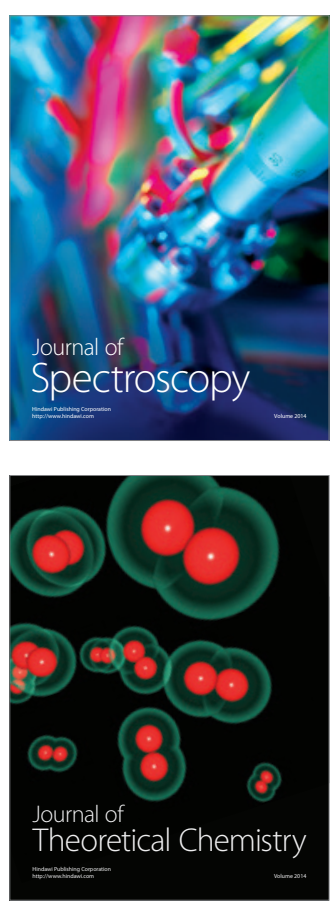
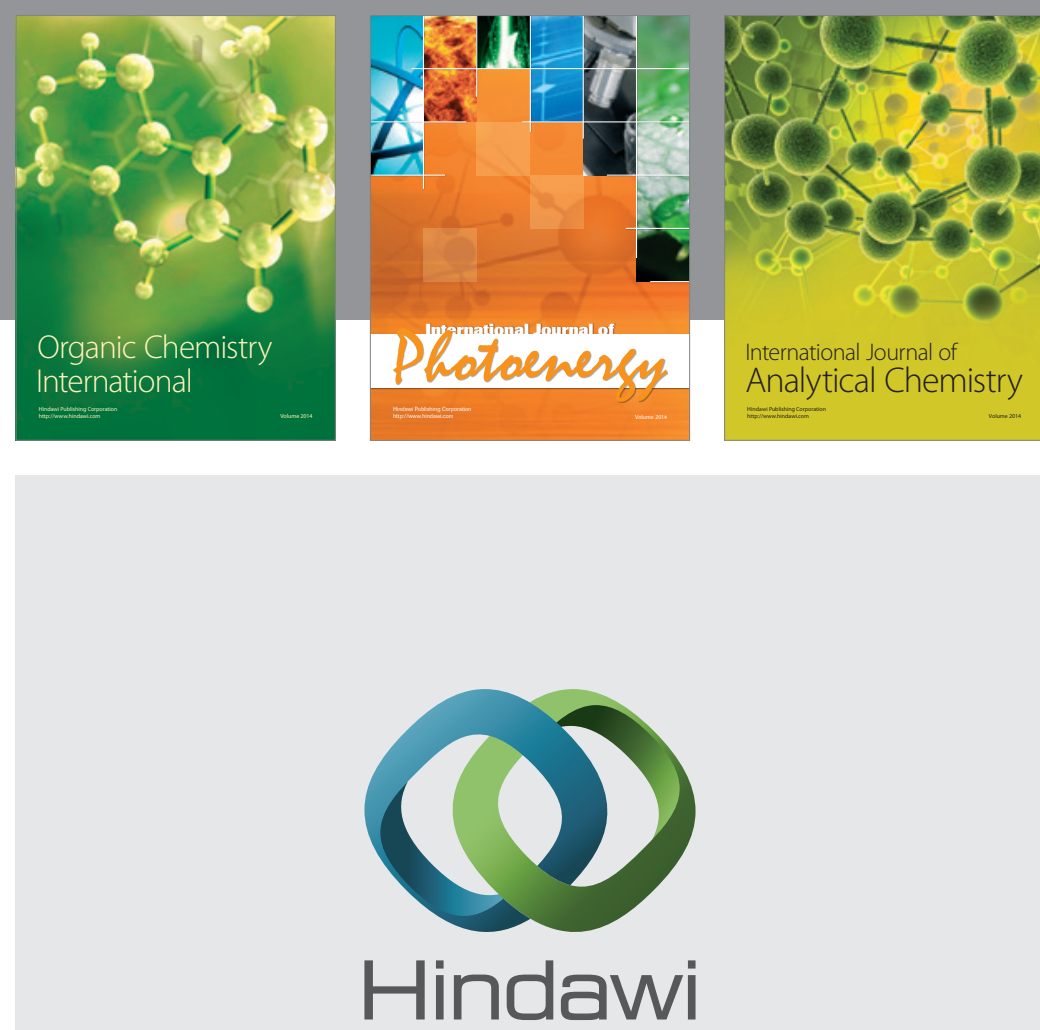

Submit your manuscripts at

http://www.hindawi.com
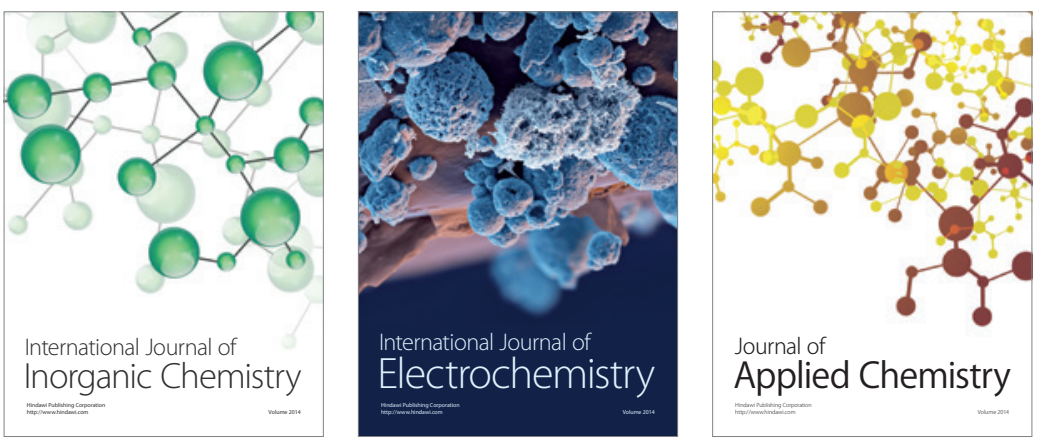

Journal of

Applied Chemistry
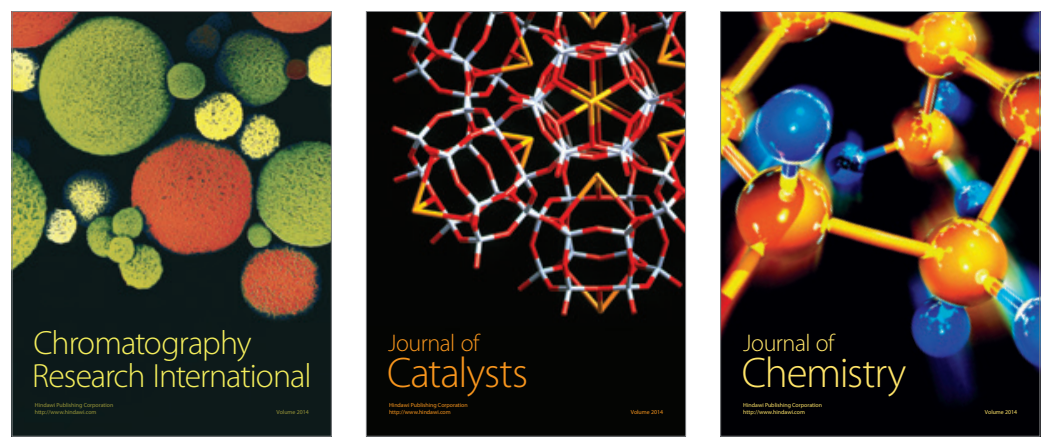
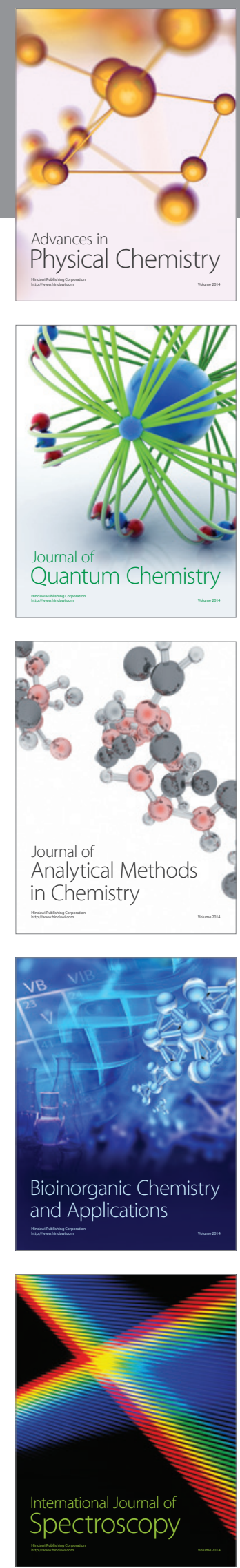